\title{
Lichens of Sokółka (Podlasie, NE Poland) as indicators of the state of air pollution Porosty Sokółki (Podlasie, Polska NE) jako wskaźniki zanieczyszczenia powietrza
}

\footnotetext{
* Dr Anna Matwiejuk, Agnieszka Kałuska, Department of Botany, Institute of Biology, University of Bialystok, Świerkowa 20B St., 15-950 Białystok,
} phone: +48 8574573 56, e-mail: matwiej@uwb.edu.pl

Keywords: urban areas, lichens, indicators of pollution, the scale of lichen

Słowa kluczowe: tereny zurbanizowane, porosty, wskaźniki zanieczyszczenia, skala porostowa

\begin{abstract}
Monitoring of lichens as bioindicators of air pollution has been conducted in Sokółka. On the basis of the occurrence of indicator epiphytic and epilithic lichen species, the scale of lichen sensitivity for the city has been developed and lichen zones have been designated. The zone pattern was not of insular character, and as a result there was no "total lichen desert". The distribution of lichen zones reflects the intensity of anthropogenic pressure within the town. The least favourable conditions for lichen growth have been recorded in the town centre, while the green areas have shown the most beneficial impact on the lichen test sites.
\end{abstract}

(c) IOŚ-PIB

\section{INTRODUCTION}

The assessment of the behaviour of the local population of lichen species as the best bioindicators of air pollution is not only of cognitive meaning but also a practical one. Biota of lichens can be an indicator of both the variety of anthropogenic environmental changes [Coppins, Coppins 2002; Cieśliński 2003] including its impurities [Richardson 1992; Kiszka 1990, 1999; Conti, Cecchetti 2001; Nash 2008], as well as real threats to human health and life [Cislaghi, Nimis 1997]. In urban and industrial areas, lichenoindication allows specifying the degree of air pollution of industrial emissions, municipal waste and vehicle emissions. The research involves the study of lichens, using their unique sensitivity to air pollution.

In Polish cities, the most common method of lichenoindication is the scale of lichens, based on the analysis of the distribution in the study area of epiphytic (arboreal) and epilithic (cave) sentinel species that distinguish the zones of differing levels of air pollution [e.g., Zurzycki 1950; Wilkoń-Michalska et al. 1968; Cieśliński 1974; Kiszka 1977, 1990, 1999; Kiszka, Kościelniak, 1996; Fałtynowicz et al. 1991; Kepel 1999; Matwiejuk 2007; Matwiejuk, Korobkiewicz 2012].

The main aim of the study was to determine the influence of the urban environment of Sokółka on lichens on the basis of lichen scale and to design lichen zones.

\section{Streszczenie}

Na terenie miejscowości Sokółka prowadzono badania z wykorzystaniem porostów jako wskaźników zanieczyszczenia powietrza. Na podstawie występowania wskaźnikowych gatunków porostów epifitycznych i epilitycznych opracowano skalę porostową dla miasta, na podstawie której wykreślono strefy lichenoindykacyjne. Nie stwierdzono „bezwzględnej pustyni porostowej”. Układ stref wegetacji porostów odzwierciedla sposób użytkowania miasta i stopień antropopresji. Najmniej korzystne warunki życia porostów odnotowano w centrum miasta, tereny zielone natomiast wykazały najbardziej korzystne oddziaływanie na lichenobiotę badanego terenu.

\section{STUDY AREA}

Sokółka (GPS: $53^{\circ} 24^{\prime} \mathrm{N} 23^{\circ} 30^{\prime} \mathrm{E}$ ) is a city located in the northeastern part of Poland, in the eastern part of Podlasie, on the edge of the Knyszyn Forest. The international railway route WarsawBiałystok-Grodno runs through Sokółka and continues towards Minsk, Vilnius, Riga, St. Petersburg and Moscow, and there is national road No. 19 running through it. Sokółka is situated $16 \mathrm{~km}$ from the Polish-Belarusian border crossing in Kuźnica Białostocka. Road transportation goes through Sokółka to all European countries. After crossing the Polish-Belarusian border in Kuźnica Białostocka, Sokókka is the first city in the European Union. The city has about 21,000 inhabitants and covers an area of $19 \mathrm{~km}^{2}$. The city is located in the area of Sokólskie Hills, in the northern part of the Podlasie Lowland, by Sokołda river [Kondracki 2002]. Sokółka's area in terms of climatic conditions lies in the zone of the Great Valleys in the land of Łomża-Grodno. The climate of this region is characterised by harsh winters and warm summers, relatively low rainfall and predominance of western winds. The average annual temperature ranges from 6.5 to $7.0^{\circ} \mathrm{C}$. The number of frosty days ranges from 50 to 60 in the year and days of frost from 110 to 138 . The thermal conditions in Sokółka are characterised by large fluctuations in temperature both in the annual and diurnal course. The duration of snow cover is $80-87$ days per year. The fog has been listed for 50 days a year, with the most 
frequent occurrence in the months: October, November and December. The average rainfall in Sokółka is approximately $589 \mathrm{~mm}$. The maximum precipitation falls in July $(89 \mathrm{~mm})$ and the maximum of thunderstorm days is for the month of July $(8.3 \mathrm{~mm})$ [www.bip. um.Sokółka.wrotapodlasia.pl].

The communication traffic through the city is a potential source of negative impact on the environment and air pollution. At the city level, concentrations of air pollutants are maintained within acceptable standards. The current status of air pollution was determined on the basis of data on the sources of emissions to air collected on the basis of activity Regional Inspectorate for Environmental Protection (WIOS). The analysis of the results indicates that the air quality is generally good and the environmental quality standards are not exceeded; the values are the average concentrations of $33.25 \mu \mathrm{g} / \mathrm{m}^{3}$ for $\mathrm{NO}_{2}$ and $8 \mu \mathrm{g} / \mathrm{m}^{3}$ for $\mathrm{SO}_{2}$ [www.bip.um. Sokółka. wrotapodlasia.pl].

\section{MATERIALS AND METHODS}

The field studies were carried out in 2010-2011 on 50 research positions. The method of data collection point was used. During the floristic studies, the current list of epiphytic and epilithic lichens occurring within the administrative boundaries of the city in urban areas located in the centre and on the outskirts of the city and the open areas was made (parks, squares, cemeteries, forests). The lichen biota occurring on the bark of trees and inhabiting the concrete substrate (columns, walls) was examined. The collected data were used to plot lichen zones. The selection of species and assigning them to individual zones were done according to a detailed analysis of their occurrence and distribution in Sokółka and ranking them in terms of their sensitivity by other authors [Hawksworth, Rose 1970; Kiszka 1990, 1999; Kepel 1999]. The species have been named following Diederich et al. [2014] and species Lecanora saxicola following Laundon [2010] and Calogaya decipiens, Calogaya pusilla, Flavoplaca citrina, Flavoplaca oasis, Polycauliona polycarpa and Rusavskia elegans following Arup et al. [2013]

\section{RESULTS}

On the basis of the analysis of epiphytic and epilithic lichen incidence in different areas of the city, the lichen scale was developed
(Table 1) and the lichen zones for Sokółka were designed (Fig. 1). In the city, not all the zones of lichen vegetation were present. There was no presence of lichen deserts: zone I (absolute lichen desert) and zone II (relative lichen desert).

The environment where the research was carried out is covered by zone III, which occurs only in spots on five posts, and by two lichen zones, IV and V, which are spatial (Table 1, Fig. 1).

ZONE III: inner zone limited vegetation. This zone was observed in five research stations where there were no epiphytic lichens found It has been determined on the basis of the presence of species that inhabit the cave concrete substrate. In this zone, there was a presence of lichens such as Calogaya decipiens, Calogaya pusilla and Lecanora saxicola. The often listed species of lichens were also those with crustose thallus: Flavoplaca citrina, Candelariella aurella, Lecanora albescens and Lecanora dispersa. All positions belonging to Zone III are located in urban areas, situated mainly on the outskirts of the city.

ZONE IV: central zone of limited vegetation. It was noticed in 20 positions. Its range includes both built-up areas, as well as a large proportion of green areas in the park on Marshal Jozef Pilsudski Street, in the parish church of St. Alexander Nevsky Cathedral and fragments of the forest. The bark of trees is covered with numerous species of foliose thalli, including Melanelixia fuliginosa, Parmelia sulcata, Phaeophyscia orbicularis, Physcia adscendens and Physcia dubia. Lichens such as Hypogymnia physodes, Melanelixia subargentifera, Physconia enteroxantha and Physconia grisea were found occasionally in the form of small thalli.

ZONE V: outer zone of limited vegetation. It is the purest designated zone in the city. In Sokółka, it was recorded at 24 positions. The zone includes buildings on the outskirts of the city and in the centre Within its borders there are green areas, such as three cemeteries (Roman Catholic, Orthodox and Jewish), two parks, a square at the train station and a fragment of the forest on Buchwałowo Estate. In this zone, very abundant species of zone IV were found, such as Candelariella xanthostigma, Hypogymnia physodes and Parmelia sulcata. Epiphytes of considerable size and well-developed thallus were noted here, e.g., Hypogymnia tubulosa and Evernia prunastri. In this zone, large numbers of fruticose thallus of Ramalina fraxinea grow on the bark of trees. The isolated thalIus of Ramalina farinacea, Ramalina fraxinea, Ramalina pollinaria and Usnea hirta was observed too.

Table 1. Zone scale of lichen distribution in Sokółka

\begin{tabular}{|c|l|l|c|}
\hline Zone & \multicolumn{1}{|c|}{ Indicator species growing on the bark of trees } & Indicator species growing on concrete & $\begin{array}{c}\text { Number } \\
\text { of stands }\end{array}$ \\
\hline I & green algae (Protococcus sp.), lack of lichens & 0 \\
\hline II & $\begin{array}{l}\text { Amandinea punctata, Lecanora conizaeoides, } \\
\text { Lepraria sp., Scoliciosporum chlorococcum }\end{array}$ & $\begin{array}{l}\text { Species nitrophilous and calciphilous } \\
\text { preferring concrete: Candelariella aurella, } \\
\text { Flavoplaca citrina, F. oasis, Lecanora } \\
\text { albescens, L. dispersa }\end{array}$ & 0 \\
\hline III & $\begin{array}{l}\text { Hypocenomyce scalaris, Phaeophyscia orbicularis, } \\
\text { Physcia adscendens, P. dubia, Polycauliona polycarpa, } \\
\text { Xanthoria parietina }\end{array}$ & $\begin{array}{l}\text { Calogaya decipiens, C. pusilla, Lecanora } \\
\text { saxicola }\end{array}$ & 5 \\
\hline $\begin{array}{l}\text { Candelariella xanthostigma, Hypogymnia physodes, } \\
\text { Melanelixia fuliginosa, M. subargentifera, Melanoxalea } \\
\text { exasperatula, Parmelia sulcata, Physconia enteroxantha, } \\
\text { P. grisea }\end{array}$ & $\begin{array}{l}\text { Phaeophyscia orbicularis, P. nigricans, } \\
\text { Physcia adscendens, P. dubia, P. caesia, } \\
\text { P. tenella, Xanthoria parietina }\end{array}$ & 20 \\
\hline $\begin{array}{l}\text { Anaptychia ciliaris, Evernia prunastri, Hypogymnia } \\
\text { tubulosa, Pleurosticta acetabulum, Ramalina farinacea, } \\
\text { R. fastigiata, R. fraxinea, R. pollinaria, Usnea hirta }\end{array}$ & Rusavskia elegans \\
\hline V & & \\
\hline
\end{tabular}




\section{DISCUSSION AND CONCLUSION}

This work demonstrates that the test method using sentinel species of epiphytic and epilithic lichens produces results, indicating the areas of the city as the most or least favourable for lichen growth, and thus also for human life. The use of lichen scale takes into account the fact that the lichens occurring locally allow one to estimate the state of the environment on the scale of a few years, or even longer. The lichen biota of Sokółka shows diversity in the city, which allowed the use of the method for determining the scale of species of lichen vegetation zones. The most important factor affecting the biodiversity of lichen biota is the spatial layout of the city, expressed mainly in the location of compact building and main roads and, on the other hand, green areas.

Sokółka next to Białystok [Matwiejuk 2007] and Narew [Matwiejuk, Korobkiewicz 2009] is the third town in the Podlasie region, where the lichen vegetation zones were set. Sokółka is distinguished by the absence of a desert lichen zone. The Narew and Białystok zones I and II show distribution point. In other Polish cities such zones occupy large areas. Lichen deserts are isolated in Kraków [Zurzycki 1950; Kiszka 1977; Kiszka, Kościelniak 1996], Toruń [Wilkoń-Michalska et al. 1968], Radom [Cieśliński 1974], Warsaw [Zimny, Kucińska 1974], Łódź [Kuziel, Halicz 1979] and Szczecin [Marska 1979], in the cities of the Tri-City agglomeration [Fałtynowicz et al. 1991] and in Poznan [Kepel 1999]. Lichen zones in many cities coincide with areas of high contamination of the air. In Kraków, the average concentration of $\mathrm{SO}_{2}$ in 2004 was $81.25 \mu \mathrm{g} / \mathrm{m}^{3}$ (in the city centre, on the main square) and $146.15 \mu \mathrm{g} / \mathrm{m}^{3}$ (in Nowa Huta), respectively, while the average concentration of $\mathrm{NO}_{2}$ was $119.35 \mu \mathrm{g} / \mathrm{m}^{3}$ (in the city centre, on the main square) and $93.75 \mu \mathrm{g} / \mathrm{m}^{3}$ (in Nowa Huta). In Kraków, a continuous increase in the concentrations of both compounds [www. bip.Kraków.pl] and the extension of zones of lichen desert is observed [Kiszka, Kościelniak 1996]. In Sokółka, where there was no desert lichen zone, the average concentrations are much lower than those quoted in Kraków and amount to $33.25 \mu \mathrm{g} / \mathrm{m}^{3}$ for $\mathrm{NO}_{2}$ and $8 \mu \mathrm{g} / \mathrm{m}^{3}$ for $\mathrm{SO}_{2}$. Zones of lichen deserts except the cities of Podlasie, Poland, have been recorded only in Kielce [Toborowicz 1976], Drezdenko [Lipnicki 1984] and Przemyśl [Kiszka 1999]. In many cities, it was found that the spatial arrangement of lichen vegetation zones is associated with the beneficial effects of green complexes and the movement of dust and gas in accordance with the morphology of the terrain, especially with the course of the river valleys and direction of winds in the area.

The lichen zone of Sokółka shows that the environment of the tested city located near the facility having a large natural complex, which is the Knyszyn Forest, indicates that this is a region with high environmental quality standards. The main sources of air pollution here are anthropogenic emissions, which consist primarily of domestic waste water emissions from the sector and the issue of communication. Due to its border location and severe communication traffic towards the international border with the Republic of Belarus, Sokółka will need retesting lichen research to track changes. Therefore, it is lichens - organisms with mutualistic nature, ecological associations representing fungi (Ascomycota and Basidiomycota) and algae (Chlorophyta and/or Cyanophyta) - that are the first response to adverse environmental factors.

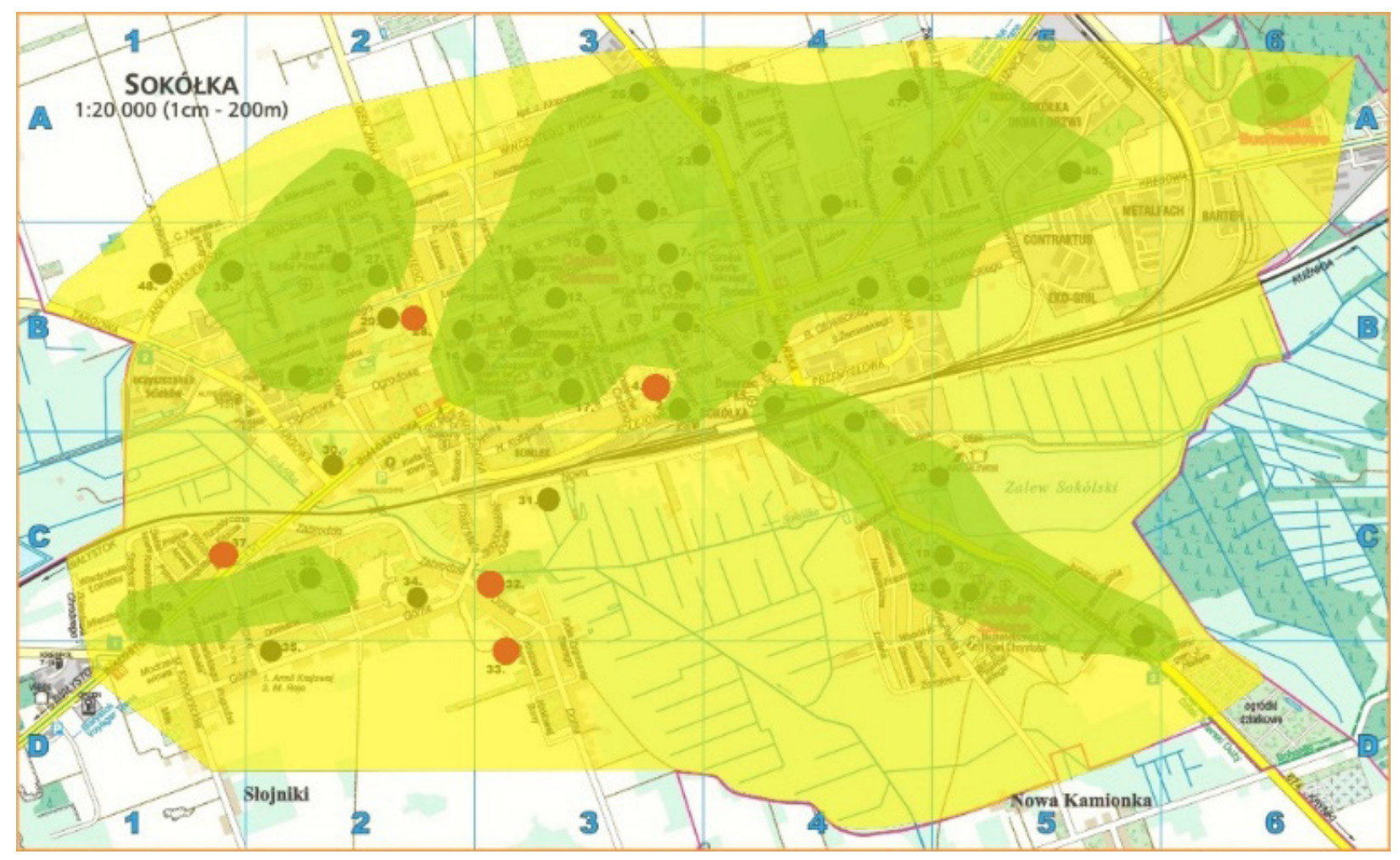

Fig. 1. A map of the zones of lichen distribution in Sokółka 


\section{REFERENCES}

ARUP U., SøCHTING U., FRÖDÉN P. 2013. A new taxonomy of the family Teloschistaceae. Nord. J. Bot. 31: 16-83.

CIEŚLIŃSKI S. 1974. Flora epifityczna porostów miasta Radom. Biuletyn Kwartalny Radomskiego Towarzystwa Naukowego 11 [3/4]: 169-189.

CIEŚLIŃSKI S. 2003. Atlas rozmieszczenia porostów (Lichenes) w Polsce Północno- Wschodniej. Phytocoenosis (N.S.) 15, Suppl. Cartogr. Geobot. 15: 1-430.

CISLAGHI C., NIMIS P.L. 1997. Lichens, air pollution and lung cancer. Nature 387(6632): 463-464.

CONTI M.E., CECCHETTI G. 2001. Biological monitoring: lichens as bioindicators of air pollution assessment - a review. Environmental Pollution 114: 471-492.

COPPINS A.M., COPPINS B.J. 2002. Indices of ecological continuity for woodland epiphytic lichen habitats in the British Isles. British Lichen Society, London.

DIEDERICH P., ERTZ D., STAPPER N., SÉRUSIAUX E., VAN DEN BROECK

D., VAN DEN BOOM P., RIES C. 2014. The lichens and lichenicolous fungi of Belgium, Luxembourg and northern France. URL: http://www.lichenology.info [28.04.2014].

FAŁTYNOWICZ W., IZYDOREK I., BUDZBON E. 1991. The lichen flora as bioindicator of air pollution of Gdańsk, Sopot and Gdynia. Monogr. Bot. 73: 1-53.

HAWKSWORTH D.L, ROSE F. 1970. Qualitative scale for estimating sulphur dioxide air pollution in England and Wales using epiphytic lichens. Nature 227: 145-148.

KEPEL A. 1999. Porosty poznania jako wskaźniki zanieczyszczenia atmosfery. Praca doktorska [manuskrypt] wykonana w Zakładzie taksonomii roślin uniwersytetu im. Adama Mickiewicza w Poznaniu: 237.

KISZKA J., KOŚCIELNIAK R. 1996. Porosty miasta Krakowa oraz waloryzacja ich warunków bioekologicznych. Stud. Ośr. Dokument. Fizjogr. 24: 21-72.

KISZKA J. 1977. Wpływ emisji miejskich i przemysłowych na florę porostów (Lichenes) Krakowa i Puszczy Niepołomickiej. Wyd. Naukowe WSP w Krakowie, Prace Monogr. 19: 5-137.

KISZKA J. 1990. Lichenoidykacja obszaru województwa Krakowskiego. Stud. Ośr. Dokument. Fizjogr. 18: 201-212.

KISZKA J. 1999. Porosty (Lichenes) oraz warunki bioekologiczne Przemyśla. Arboretum Bolestraszyce. Zeszyt 6, ss. 86.

KONDRACKI J. 2002. Geografia regionalna Polski. PWN, Warszawa.
KUZIEL S., HALICZ B.1979. Występowanie porostów epifitycznych na obszarze Łodzi, Łódzkie Towarzystwo Naukowe, Sprawozdanie z czynności i posiedzeń naukowych 33.3: 1-8.

LAUNDON J. R. 2010. Lecanora antiqua, a new saxicolous species from Great Britain, and the nomenclature and authorship of $L$. albescens, $L$. conferta and $L$. muralis. Lichenologist 42. 6: 631-635.

LIPNICKI L. 1984. Porosty miasta Drezdenka i najbliższej okolicy. Fragm. Flor. et Geobot. 28(2): 221-239.

MARSKA B. 1979. Z badań nad porostami miasta Szczecina. Zesz. Nauk. Akademii Rolniczej w Szczecinie. Rolnictwo XXIISeria Przyrodnicza 77: 205-215.

MATWIEJUK A., KOROBKIEWICZ K. 2012. Stan badań bioty porostów w miastach Polski. Ochrona Środowiska i Zasobów Naturalnych 51: 85-105.

MATWIEJUK A. 2007. Porosty Białegostoku, jako wskaźniki zanieczyszczenia atmosfery. Tom II. Wydawnictwo Ekonomia i Środowisko, Białystok, ss. 1-102.

NASH T.H. 2008. Lichen sensitivity to air pollution. W: Nash T.H. (red.). Lichen biology. Cambridge University Press: 299-314.

RICHARDSON D.H.S. 1992. Pollution monitoring with lichens. The Richmond Publishing, Slough

TOBOROWICZ K. 1976. Porosty miasta Kielc i najbliższej okolicy. Fragm. Flor. Geobot. 22.4: 574-603.

WILKOŃ-MICHALSKA J., GLAZIK N., KALIŃSKAA. 1968. Porosty miasta Torunia. Acta Univ. Nic. Copern., Biologia 29: 209-253.

www.bip.Kraków.pl/zalaczniki/dokumenty/2239 - Raport o stanie miasta 2004. Ochrona Środowiska i Rolnictwo 41>65.

www.bip.um.Sokółka.wrotapodlasia.pl - Raport S-19 Sokółka poprawki GDDKiA - zmiany. Droga ekspresowa S-19 - obwodnica Sokółki (długość 9,617km). Raport o oddziaływaniu na środowisko.

www.bip.um.Sokółka.wrotapodlasia.pl - Strategiczna ocena oddziaływania na środowisko. Prognoza oddziaływania na środowisko. Zmiany. Studium uwarunkowań i kierunków zagospodarowania przestrzennego gminy Sokółki. 2009. [Prognoza oddziaływania 2009.pdf].

ZIMNY H., KUCIŃSKAK. 1974. Porosty Warszawy jako biowskaźniki zaburzeń środowiska miejskiego. Przegląd Informacyjny Zieleń Miejska. Instytut Gospodarki Komunalnej, Warszawa, 10/1: 13-22

ZURZYCKI J. 1950. Badania nad nadrzewnymi porostami Krakowa i okolicy. Mat. do Fizjogr. Kraju 24 Kraków: 1-30 